\title{
Population structure, biomass and production of the West African lucinid Keletistes rhizoecus (Bivalvia, Mollusca) in Sivibilagbara swamp at Bodo Creek, Niger Delta, Nigeria
}

\author{
N. Zabbey $\cdot$ A. I. Hart $\cdot$ W. J. Wolff
}

Received: 19 January 2010/Revised: 28 June 2010/ Accepted: 16 July 2010/Published online: 30 July 2010

(C) The Author(s) 2010. This article is published with open access at Springerlink.com

\begin{abstract}
The West African lucinid bivalve Keletistes rhizoecus (Oliver, Basteria 50:47-64, 1986) is only known from the Niger Delta in Nigeria. Due to inaccessibility of its habitat population biology, growth parameters, biomass, and annual secondary production are unknown. The danger of oil pollution threatens the localities where this species occurs. Hence, ecological characteristics of the species were investigated quantitatively from May 2007 to April 2008 at Sivibilagbara, a protected mangrove swamp at Bodo Creek in the lower Niger Delta. Density of this chemosymbiotic lucinid was significantly higher than data previously reported. Temporal size distribution of
\end{abstract}

Handling editor: Pierluigi Viaroli

N. Zabbey $(\bowtie)$

Department of Animal Science and Fisheries, Faculty

of Agriculture, University of Port Harcourt,

Choba PMB 5323, Rivers State, Nigeria

e-mail: zabbey1@yahoo.com

\section{A. I. Hart}

Department of Animal and Environmental Biology, Faculty of Science, University of Port Harcourt, Choba, Nigeria

\section{W. J. Wolff ( $($ )}

Department of Marine Benthic Ecology and Evolution, University of Groningen, c/o Stationsweg 84-3, 6711 PV Ede, P.O. Box 14, 9750 AA Haren, The Netherlands e-mail: W.J.Wolff@rug.nl the population showed minor changes due chiefly to recruitment and growth increments. Recruits peaked in February and September. The species lifespan is estimated to be 1.2 years. The biomass and production values are relatively high, but comparable to those of other bivalve species, especially those from nearby Andoni intertidal flats.

Keywords Keletistes rhizoecus - Biomass · Secondary production $\cdot \mathrm{P} / \mathrm{B} \cdot$ Niger Delta Chemoautotrophy

\section{Introduction}

The family Lucinidae currently has 500 extant species (Taylor \& Glover, 2006), and 32 species are known from tropical West Africa (von Cosel, 2006). Lucinidae is one of six bivalve families presently known to be chemosymbiotic (Schweimanns \& Felback, 1985; Taylor \& Glover, 2000; Glover et al., 2004). Taylor \& Glover (2006) consider sulphide-oxidising symbiosis obligate in members of the Lucinidae, having been confirmed in at least 30 species representing 18 genera from several distinct clades. Although a large part of nutrition in lucinids is obtained from endosymbiosis (Taylor \& Glover, 2000), they also feed on exogenous particles (Reid \& Slack-Smith, 1998).

Lucinids occupy a broad range of habitats, including inhospitable biotopes. The habitat ranges from 
intertidal to off-shore muds and sands, stretching to depths of 2,100 m (Barnes \& Hickman, 1999; Taylor \& Glover, 2006); mangrove muds (Oliver, 1986; Lebata, 2001), sites of high organic inputs (Reid \& Brand, 1986) and offshore locations where sunken vegetation accumulates (von Cosel \& Bouchet cited in Taylor \& Glover, 2006). Some lucinid species are associated with cold seeps and mud volcanoes (Carney, 1994; Salas \& Woodside, 2002), oxygen minimum zones (Oliver \& Holmes, 2006), and recently, Glover et al. (2004) reported one species from hydrothermal vents. Detailed descriptions of the external morphology and internal anatomy of members of the Lucinidae are provided in Taylor \& Glover (2006); they reported presence of the symbiotic bacteria in single vacuoles within bacteriocytes in the ctenidia.

The West African lucinid Loripes (Keletistes) rhizoecus Oliver, 1986, was described from the Niger Delta (Oliver, 1986); holotypes used to describe the species were gotten from intertidal mangrove root peat at Bodo Creek, Odeama and Forcados. Keletistes was described as a new subgenus of the Loripes group containing four subgenera: Loripes s.s., Wallucina, Pillucina (syn. Sydllorina) and Keletistes (Oliver, 1986). Subsequent authors (e.g. Glover \& Taylor, 2001) raised Keletistes to generic rank; hence, we call our species Keletistes rhizoecus. The species' geographic range is not yet known with certainty, but current available records (von Cosel, 2006) suggest that this lucinid is restricted to the Niger Delta environment, while its closest relative, Loripes aberrans, has been reported widely along the West African coast from Mauritania to Congo Kinshasa (von Cosel, 2006).

The Niger Delta is the hub of oil production in Nigeria. Oil pollution, mostly caused by equipment failures and oil theft, substantially degrades the delta network of alluvial swamps and lands, creeks and rivers. Apparently, there is no consensus on the number of oil spills and volume of oil spilling into the delta environment, as the operating companies and government of Nigeria keep conflicting data (Amnesty International, 2009). However, a recent report by UNDP (2006) put the annual average number of oil spills and volume spilled into the delta environment at 273 and 115,000 barrels, respectively, making the delta one of the most oil spill vulnerable areas in the world (Steiner, 2008). Our study of K. rhizoecus might well be a last chance to study this species in non-polluted conditions.
Over two decades have passed since $K$. rhizoecus was first described, but scientific literature on the species has not progressed beyond taxonomic description and reviews (Oliver, 1986; Glover \& Taylor, 2001; Taylor \& Glover, 2006; von Cosel, 2006). Currently, there seems to be a shift from mere nomenclatural analysis to focused studies on the biology of lucinids, primarily due to their unique chemoautotrophic property (von Cosel, 2006). In Oliver's (1986) classic systematic description of K. rhizoecus, brief information on habitat of the species, density and associated faunas were provided. However, we are not aware of any published account(s) on the population biology of K. rhizoecus; the obvious absence of refereed literature on population parameters of the bivalve was reaffirmed by Taylor (personal communication). Data on biomass and secondary production of the species are similarly lacking. The present study, therefore, assesses population structure and dynamics, growth, mortality, biomass and production of $K$. rhizoecus from an 'undisturbed' and protected population at Bodo Creek in the lower Niger Delta basin of Nigeria.

\section{Materials and methods}

\section{Study area}

Bodo Creek is a network of creeks and creeklets on the upper reaches of the Andoni-Bonny river system. The creek adjoins Bodo community, administratively located in the Gokana local government area of Rivers State, Nigeria (Fig. 1). The creek structure and pattern of hydrology have been described by Onwugbuta-Enyi et al. (2008). Traditionally, Bodo Creek is a strong livelihood support base for the people of the Bodo community and their neighbours (Powell et al., 1985). The creek provides readily incentives for fishing, transportation, cassava fermentation, fuel wood production, domestic waste disposal, small-scale aquaculture and sand dredging (Onwugbuta-Enyi et al., 2008). Access to bioresources within Bodo Creek is open to every person including migrant fisher folks. There are no organised management structures in place to check and regulate exploitation rates in the creek basin beyond weak community-imposed regulations, which are grossly violated due to lack of enforcement. However, the Sivibilagbara protected mangrove swamp (Fig. 1) fringing Dor Nwezor channel stands 


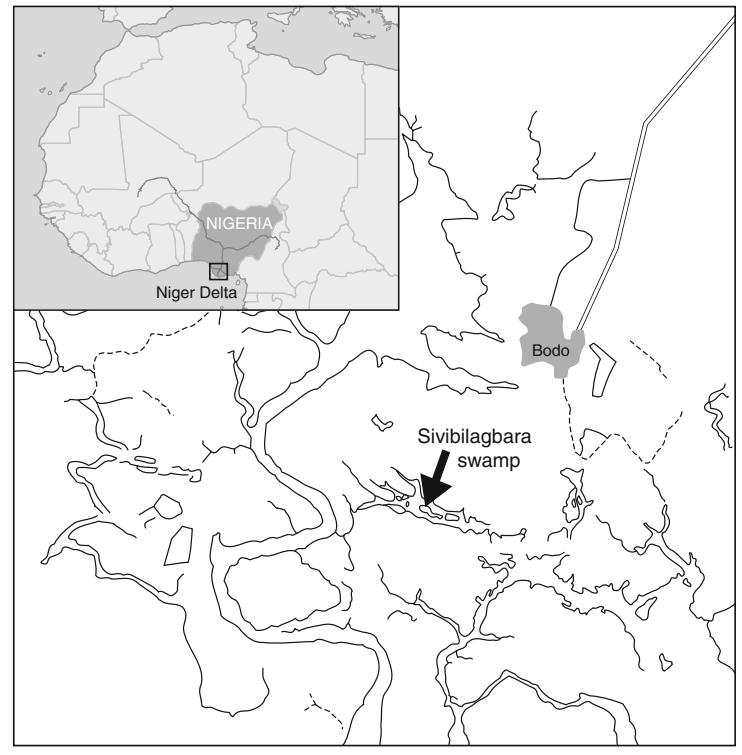

Fig. 1 Map showing Bodo Creek area in the Niger Delta in Nigeria and the sampled station. The arrow indicates Sivibilagbara swamp

out a rare exception. Over 30 years ago, a highly respected communal moratorium was issued, declaring the Sivibilagbara mangrove block closed from entry and from any kind of resource removal.

This study was conducted at the protected Sivibilagbara mangrove swamp located approximately at latitude $6^{\circ} 72^{\prime} \mathrm{N}$ and longitude $5^{\circ} 32^{\prime} \mathrm{E}$ (Fig. 1). The swamp dimension is approximately $105 \mathrm{~m} \times 42 \mathrm{~m}$ $\left(4,410 \mathrm{~m}^{2}\right)$. The vegetation is homogenously red mangrove, Rhizophora racemosa Meyer, with closed structural architecture and very thick intertwined crowns. The impenetrable tangle of the mangal prop roots makes movement within the forest difficult. The substratum is made up of spongy-compact peaty clay (chikoko) that can be cut into blocks; the swamp substratum is somewhat higher (which points at years of uninterrupted sediment accretion by the mangroves) compared to other mangrove swamps in the neighbourhood that are constantly exploited, disturbed and rammed. Temperature of interstitial water in the Sivibilagbara swamp ranges between 26 and $31^{\circ} \mathrm{C}$ (mean $\pm \mathrm{SD}=28.7 \pm 1.45$ ). Salinity fluctuates gradually between 15 and 23 psu with a mean of $17.9 \pm 2.56$. Dissolved oxygen concentration (DO) is generally low with a range of 0 to $2 \mathrm{mg} \mathrm{l}^{-1}(0.383 \pm$ 0.695). Hydrogen ion concentration $(\mathrm{pH})$ fluctuates between neutrality and alkaline values. It ranged from
7.0 to 9.46 , having a mean of $7.76 \pm 0.645$. The nutrient ions, nitrate and phosphate, alternated between $0.26-2.85(1.553 \pm 0.997) \mathrm{mg} \mathrm{l}^{-1}$ and $0.01-$ $0.33(0.263 \pm 0.272) \mathrm{mg} \mathrm{l}^{-1}$, respectively.

Field and laboratory procedures

Based on the pioneer work on $K$. rhizoecus of Dr. John Hartley, reported in Oliver (1986), which reported Bodo Creek as one of the species' endemic habitats in the Niger Delta, we surveyed mangrove swamps flanking Dor Nwezor channel in April 2007 to obtain preliminary data on the species horizontal distribution and intensity of occurrence. The reconnaissance data obtained reveal high abundance of the bivalve at Sivibilagbara swamp compared to other swamps in the creek basin. At some other locations, no specimens were found in replicate samples. We decided to focus on the Sivibilagbara protected swamp population, to generate data on this lucinid under undisturbed 'pristine' conditions.

Three replicate benthic samples were collected monthly at low tide at Sivibilagbara swamp for 1 year (see Fig. 1): from May 2007 to April 2008. The samples were dug out from $20 \mathrm{~cm} \times 20 \mathrm{~cm}$ quadrat according to the method of Sasekumar $(1974,1984)$. The replicate samples were pooled, sieved with $1 \mathrm{~mm}$ screen and preserved with $10 \%$ borax buffered formalin. A list of macrofaunal species on mangrove stems (from the base to $50 \mathrm{~cm}$ ) was compiled. The lucinid bivalves and other associated animals were sorted in the laboratory from preserved residues in white plastic trays and counted. The shell length of each lucinid specimen was measured to the nearest $0.01 \mathrm{~mm}$ (the longest antero-posterior distance of the shell) with electronic callipers and grouped into $1 \mathrm{~mm}$ size classes. The bivalves in each size class were opened and all flesh (tissues) shucked, blotted and weighed to obtain wet weight in grams. Dry weight was determined after oven drying the specimens for $72 \mathrm{~h}$ at temperature of $60^{\circ} \mathrm{C}$ at which time constant weight was attained. Data obtained from the above measurements were used to determine population parameters, biomass and production. No corrections were made for weight loss due to the formalin. Density was calculated as in Malaquias \& Sprung (2005), while biomass and annual production were estimated using the sizefrequency method (Hynes, 1961; Hynes \& Coleman, 1968; O’Hanlon \& Bolger, 1997), which involves 
summing losses between successive size classes. In order to avoid overestimation of production from the largest size class, the "times loss factor" (last column) was arbitrarily reduced by 1 .

The FAO-ICLAM stock assessment tool (FiSAT) was used (Gayanilo et al., 2005) to determine population parameters [mortality, growth coefficient $(K)$ and recruitment]. The annual growth rates of the bivalve were fitted to the von Bertalanffy growth equation

$L_{t}=L_{\infty}-\left(L_{\infty}-L_{0}\right) e^{-k t}$,

where $L_{t}$ is length at age $t, L_{0}$ is a constant and represents length at age $0, L_{\infty}$ is a constant representing maximum possible length and $K$ is the growth coefficient representing the rate $\left(\right.$ year $^{-1}$ ) at which growth approaches the asymptotic length.

To proceed, data were first subjected to a PowellWetherall plot to obtain estimates of $L_{\infty}$ (Pauly, 1987). Time-series weighting of samples was carried out followed by selection of the points for the regression line. Those points that gave a high correlation coefficient passing as a straight line through several points were selected. The estimate of $L_{\infty}$ was thus derived.

The $L_{\infty}$ value was then seeded in the ELEFAN1 routine (Gayanilo et al., 1989, 2005) to scan $K$ values with variable starting points (i.e. the starting length and starting sample). The best combination of $K$ together with starting length and starting sample were also produced in this routine.

These values were used as inputs in the ELEFAN 1 routine to produce the curve of the normal and restructured length frequency graphs and the corresponding Rn (index of goodness-of-fit).

The growth performance index $\phi^{\prime}$ was determined using the formula

$\phi^{\prime}=\log _{10} K+2 \log _{10} L_{\infty}$,

where $K$ is the growth coefficient of the von Bertalanffy growth formula and $L_{\infty}$ is the asymptotic length.

Recruitment patterns of species were determined using the restructured length frequency data. The Hasselblad's NORMSEP (Pauly, 1986) method was used to estimate normal distributions to produce peaks for the recruitment patterns. However, in this model two assumptions are made: (1) that all animals in a given set of data grow in accordance with a single set of growth parameters and (2) that recruitment occurs in 11 months only (Gayanilo et al., 1989).

Longevity $\left(t_{\max }\right)$ of the species was obtained using $t_{\max }=\frac{3}{K}$,

where $K$ is the growth coefficient of the von Bertallanffy growth formula.

\section{Results}

A total of 12 species of macrofauna were found on the mangrove main trunks and prop roots at Sivibilagbara, surveyed from the base to $50 \mathrm{~cm}$ height. The animals were Gastropoda: Thais califera, T. coronata, Littorina angulifera; Bivalvia: Crassostrea gasar; and Crustacea: Sphaeroma rugicauda, Chthamalus dentatus, Clibanarius sp., Gionopsis pelli, Sesarma huzardi, Metagrapsus sp., Pachygrapsus gracilis and P. traversus.

Thirteen macrofauna species were isolated from the same peaty sediments with the bivalve Keletistes, namely: crabs Gionopsis pelli, Sesarma alberti, Panopeus africanus, Callinectes amnicola; burrowing shrimps Upogebia fulcata, Callianassa sp.; and polychaetes Arenicola sp., Nereis sp., Capitella capitata, Notomastus sp., N. tenuis, Platynereis sp. and Marphysa sp. These 13 associated macrobenthic infauna species were less abundant and infrequently encountered, except $U$. fulcata which occurred regularly in sizeable numbers.

A total of $1,523 \mathrm{~K}$. rhizoecus specimens were recovered from the 12 monthly samples. Density was least in May $\left(717 \mathrm{~m}^{-2}\right)$ and peaked in April $\left(1,583 \mathrm{~m}^{-2}\right)$.

Individual sizes of $K$. rhizoecus measured range from 2.5 to $10.5 \mathrm{~mm}$. The pre-reproductive size spectrum (taken as individuals $\leq 4.5 \mathrm{~mm}$ ) constituted $47 \%$ of the population. Fifty-three percent were made up of adults $(5.5-10.5 \mathrm{~mm})$. Individuals in the 4.5 and $5.5 \mathrm{~mm}$ shell length classes predominated, each class contributing $22.5 \%$ to the overall population, whereas the largest-sized specimens $(10.5 \mathrm{~mm})$ encountered were relatively few $(0.07 \%)$.

The monthly changes in population structure are presented in the histograms in Fig. 2. The monthly 
Fig. 2 Length frequency distribution of Keletistes rhizoecus from

Sivibilagbara Swamp from May 2007 to April 2008
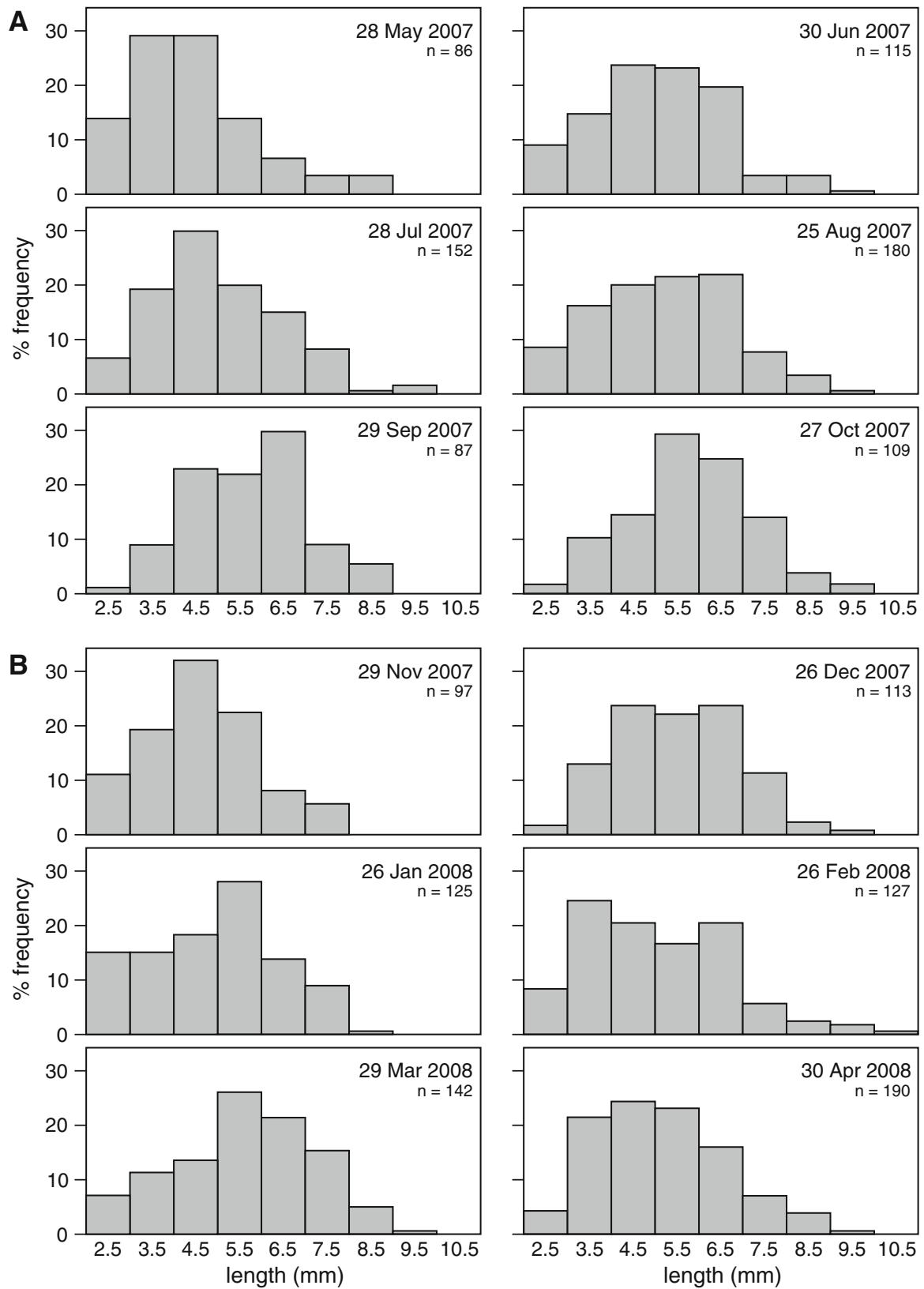

size distributions were almost similar with only slight changes due to recruitment and growth increments. Individuals in the $4.5-6.5 \mathrm{~mm}$ size spectrum dominated the population throughout the year. While the lower size categories (2.5 and $3.5 \mathrm{~mm}$ ) were consistently represented in the population, individuals in the upper size limits (9.5 and $10.5 \mathrm{~mm}$ ) occurred infrequently in the samples, having the least number of individuals throughout the study.
A pattern of continuous recruitment (see Fig. 3) with two distinct peaks in February and September was realised; the former being the highest pulse. The highest intensity of cumulative recruitment (63\%) occurred between May and November 2007, while $36 \%$ of the net recruitment occurred from December to March 2008.

The pooled length frequency data subjected to a Powell-Wetherall plot (Fig. 4) gave an asymptotic 


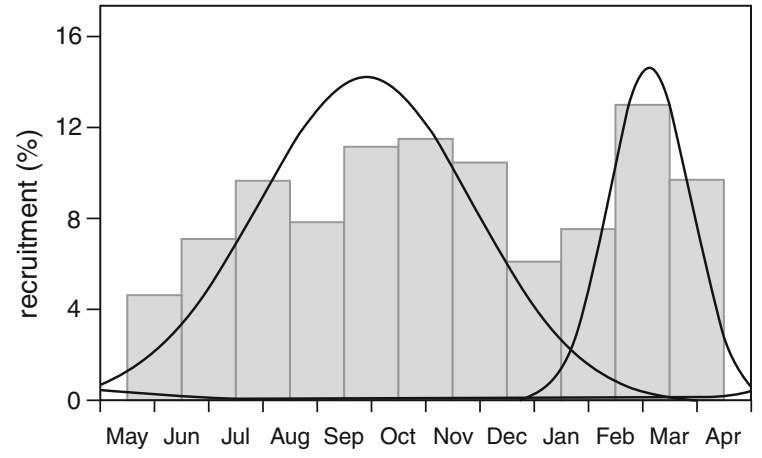

Fig. 3 Monthly recruitment pattern of Keletistes rhizoecus at Sivibilagbara Swamp. Histograms give the relative percentage of recruits per month; bell-shaped curves show the two recruitment peaks

length $\left(L_{\infty}\right)$ of $10.51 \mathrm{~mm}$. When the value was seeded into ELEFAN 1, a best ' $K$ ' (growth coefficient) of 2.50 was realised (Fig. 5) at goodness-of-fit $R n=0.147$. The growth performance index or $\phi^{\prime}$ was 2.44. Maximum length predicted for the species is $10.71 \mathrm{~mm}$. Total mortality of the species was relatively high $(Z=7.79)$ based on a length-converted 'catch curve' (Fig. 4), using input variables of $K=2.50$ and $L_{\infty}=10.51 \mathrm{~mm}$ (Fig. 5). The Powell-Wetherall plot also provides an estimate of $Z / K=3.05$, resulting in $Z=7.63$. Longevity $\left(t_{\max }=3 / \mathrm{K}\right)$ of the species is estimated to be 1.2 years.

Data on biomass and annual secondary production are presented in Table 1. The estimated average biomass (gram dry weight per $\mathrm{m}^{2}$ ) of $K$. rhizoecus is $3.913 \mathrm{~g} \mathrm{~m}^{-2}$. Individuals in the $6.5-7.4$ size bracket were the greatest contributors $(24.6 \%)$ to the net biomass, followed by those in the range 5.5-6.4 $\left(0.8002 \mathrm{~g} \mathrm{~m}^{-2} ; 20.4 \%\right)$ and 7.5-8.4 (0.6092 $\mathrm{g} \mathrm{m}^{-2}$; $15.6 \%)$, while the smallest size class (2.5-3.4)

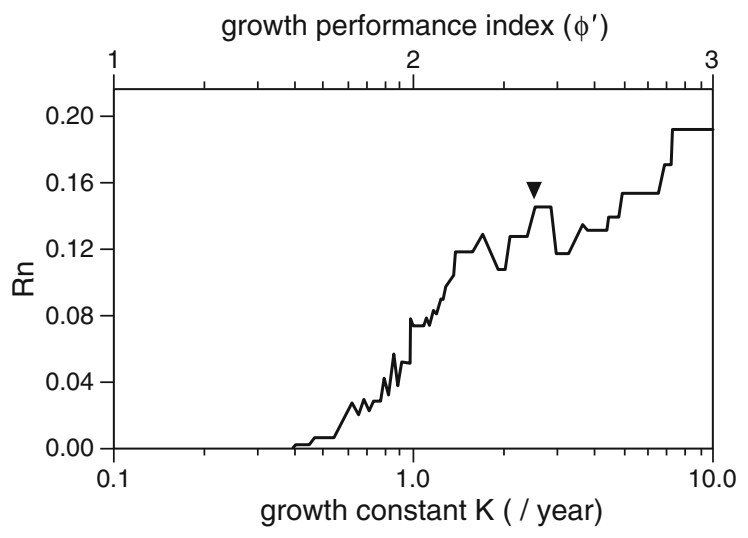

Fig. 5 Growth coefficient $(K)$ and growth performance index $(\phi)$ in Keletistes rhizoecus determined using ELEFAN 1 procedure $(K=2.50 ; \phi=2.44 ; \mathrm{Rn}=0.147)$

recorded also had the least value of $0.0714 \mathrm{~g} \mathrm{~m}^{-2}$. The annual production is $11.205 \mathrm{~g} \mathrm{~m}^{-2}$ year $^{-1}$, while the production-biomass ratio ( $\mathrm{P}: \mathrm{B})$ is 2.863 (Table 1).

\section{Discussion}

One major challenge of this study is the lack of data on K. rhizoecus (except those of Oliver, 1986) for comparative interpretation of results. The monthly density of the species was over $200 \%$ greater than the maximum density reported in Oliver (1986). He recorded a maximum abundance of $300 \mathrm{~m}^{-2}$ for the species at the sites sampled at Bodo, Odeama and Forcados-though no distinctions were reported with regard to the different geographic densities, and the sampling duration was limited to the dry season. The wide disparity between the densities of our survey and the pioneer datum above cannot be attributed to human impacts. There is no fishery for Keletistes, at
Fig. 4 Length frequency analyses of Keletistes rhizoecus at Sivibilagbara: A length-converted 'catch curve' used to calculate total mortality $Z$ based on $K=2.50$ and $L_{\infty}=10.51 \mathrm{~mm}$;

B Powell-Wetherall plot used to calculate $L_{\infty}$ and $Z / K$. A linear regression line was fitted to the darkened points in each plot
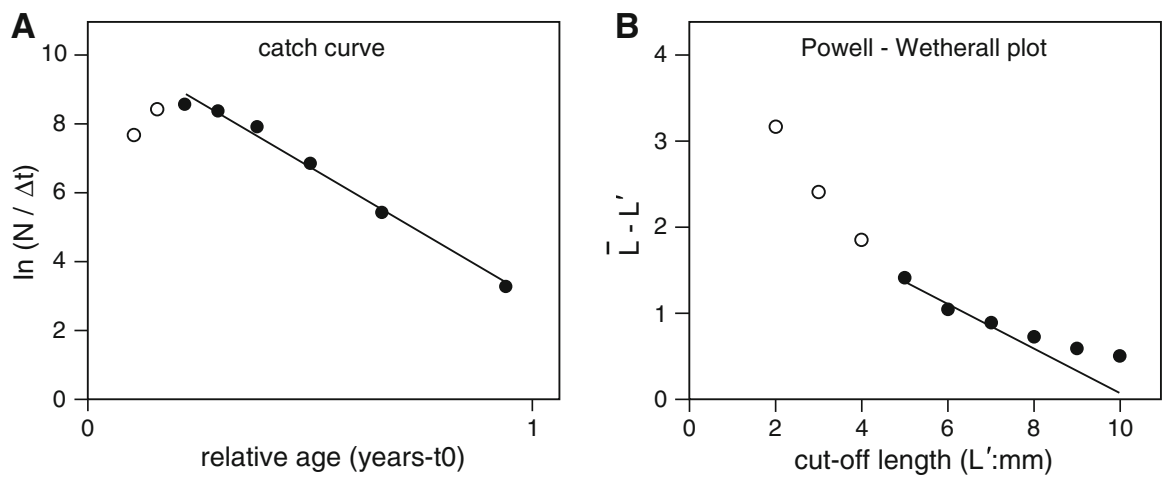
Table 1 Average biomass and annual secondary production of Keletistes rhizoecus at Sivibilagbara Swamp, Bodo Creek, Nigeria

\begin{tabular}{lllllllll}
\hline $\begin{array}{l}\text { Size class } \\
(\mathrm{mm})\end{array}$ & Average $N$ & $\begin{array}{l}\text { Average } \\
\text { no. } \mathrm{M}^{2}\end{array}$ & $\begin{array}{l}\text { Mean } \\
\text { wt }(\mathrm{mg})\end{array}$ & $\begin{array}{l}\text { Biomass } \\
\left(\mathrm{g} / \mathrm{m}^{2}\right)\end{array}$ & $\begin{array}{l}\text { No. of } \\
\text { lost } \mathrm{m}^{2}\end{array}$ & $\begin{array}{l}\text { Wt at loss } \\
(\mathrm{mg})\end{array}$ & $\begin{array}{l}\text { Wt loss } \\
\left(\mathrm{gm}^{2}\right)\end{array}$ & $\begin{array}{l}\times 8 \text { production } \\
\left(\mathrm{gm}^{2}\right)\end{array}$ \\
\hline $2.5-3.4$ & 10 & 83.3 & 0.8563 & 0.0714 & -100.0 & 0.99 & -0.09902 & -0.79216 \\
$3.5-4.4$ & 22 & 183.3 & 1.1451 & 0.2099 & -58.3 & 1.63 & -0.09510 & -0.76080 \\
$4.5-5.4$ & 29 & 241.7 & 2.3211 & 0.5609 & 0.0 & 2.77 & 0.00000 & 0.00000 \\
$5.5-6.4$ & 29 & 241.7 & 3.3113 & 0.8002 & 41.7 & 3.99 & 0.16640 & 1.33119 \\
$6.5-7.4$ & 24 & 200.0 & 4.8164 & 0.9633 & 108.3 & 5.66 & 0.61291 & 4.90324 \\
$7.5-8.4$ & 11 & 91.7 & 6.6457 & 0.6092 & 58.3 & 8.00 & 0.46669 & 3.73355 \\
$8.5-9.4$ & 4 & 33.3 & 9.6314 & 0.3210 & 16.7 & 10.58 & 0.17636 & 1.41085 \\
$9.5-10.4$ & 2 & 16.7 & 11.6250 & 0.1938 & 8.3 & 15.99 & 0.13327 & 1.06615 \\
$10.5-11.4$ & 1 & 8.3 & 22.0000 & 0.1833 & 8.3 & 4.69 & 0.03909 & 0.31269 \\
& Total biomass $(\mathrm{B})$ & & 3.913 & Total production (P) & 11.205 \\
& & & & P:B ratio & & 2.86342
\end{tabular}

Negative values for 'No. of Lost' represent recruitment

$N$ no. of individual belonging to each size class

least at Bodo Creek, which most likely is due to the small size $(\leq 10.5 \mathrm{~mm})$ of the species and its secretive habitat. Infaunal bivalves such as razor clam (Tagelus adansonii) and tellins (Tellina nymphalis) that are exploited for food at Bodo Creek have associated features such as paired burrows noticeable at the sediment surface which betray their presence. No such marking features were detected for $K$. rhizoecus, or probably such revealing characteristics are too small to have been noticed. When fisher folks encountered at the creek were interviewed and shown specimens, the species was unknown to many of them.

Predatory crabs such as $G$. pelli and $P$. africanus present at the swamp (see discussion below) and molluscivorous finfishes that visit mangrove swamps to feed (Sasekumar et al., 1984) are potential predators of $K$. rhizoecus. They would inevitably cash in on the tranquillity occasioned by the absence of physical anthropogenic disturbances, to prey more on the lucinids at the studied location. Physical disturbances by humans, particularly trampling, which is precluded from Sivibilagbara, most likely account for the low abundances of $K$. rhizoecus at neighbouring mangrove swamps (our reconnaissance survey) and elsewhere in the Niger Delta (Oliver, 1986). Trampling has been noted as an important physical disturbance that impacts on macrozoobenthos diversity and recruitment (Rossi \& Chapman, 2003; Rossi et al., 2007), population dynamics and distribution (Contessa \& Bird, 2004). K. rhizoecus lives in the surficial sediments (maximum depth $=3 \mathrm{~cm}$; Oliver, 1986) and would suffer severe crushing by human intruders or will be prone to walkburial risk to sediment strata beyond the survival limit of the lucinid, or to both. However, the Sivibilagbara lucinid population may have suffered only some unintended losses resulting from our intrusions, aside the individuals taken in our samples (Rossi et al., 2007).

It is assumed that some larvae or recruits of K. rhizoecus produced at Sivibilagbara are supplied by tide to neighbouring swamp environments, thereby buffering or maintaining the species stocks at those recipient locations. The species fertilisation ecology, larval biology and migration pattern are not known yet, however, but it seems the life history of many bivalves is generally identical: after the release of gametes in the water column, a planktonic larval stage ensues, followed by settlement on the sedimentary floor, then a demersal juvenile and adult stage. Redistribution of species through migration, which is mediated by complex interaction of environmental and biological factors, occurs mainly at the planktonic stage leading to variable abundance patterns between the intertidal, subtidal and coastal habitats (Beukema, 1993; Dankers \& Zuidema, 1995; Dankers et al., 1999). K. rhizoecus' home-range is limited to mangrove swamps, having close association with Rhizophora roots (Oliver, 1986), and has not 
been reported from open, unvegetated tidal platforms or from subtidal sediments.

It is presumed that the $1-\mathrm{mm}$ screen used in sieving our samples may have lost individuals smaller than the smallest-sized class $(2.5 \mathrm{~mm})$ recorded. Wolff et al. (1993) reviewed variations in relative percent of macrobenthos lost (in terms of number) according to mesh sizes of sieve used. Moreover, there is a consensus amongst many workers (Rees, 1984; Zwarts \& Esselink, 1989) that the smaller the mesh of the screen the more the animals retained, due to retention of individuals in the smaller class brackets which pass through large meshes. However, the same sieve $(1 \mathrm{~mm})$ used in the present study had retained small-sized bloody cockle (Anadara senilis) specimens of $1.5 \mathrm{~mm}$ in a related study of infaunal macrobenthos on tidal flats of Bodo Creek (Zabbey, in preparation).

Alternatively, it is likely that individuals smaller than our minimum size were missed out during sorting (Rees, 1984), but such consistent no detection for 12 months is quite slim. Nevertheless, Cardoso et al. (2006) reported that many bivalves (including small-sized species) produce settling larvae (spats) that are large enough to cope with the grain sizes of their settlement bed. We presume (until proven otherwise) that the production of large-sized recruits applies for K. rhizoecus.

Oliver (1986) reported the crab G. pelli as a probable predator of $K$. rhizoecus. In this study, we did not determine predation directly through stomach content analysis but we suspect, like in the above, that another crab, the African mud crab, P. africanus, is likely a more severe predator on K. rhizoecus as pieces of macerated valves were also seen in shredded cast around the crab burrows. G. pelli live partly in burrows dug mainly at the base of mangroves from where it emerges at low tide to feed at the sediment surface (Ansa, 2004; and this study), even as far as the lower unvegetated mudflat and lowwater marks which $K$. rhizoecus does not inhabit. $G$. pelli is also a good climber and makes occasional arboreal shuttles between mangrove tree stems, hanging prop roots and the sedimentary floor. On the contrary, $P$. africanus moves very slowly, does not climb, lives entirely in sediments and has relatively stronger claws which would more efficiently crush the shell-valves of the lucinid than those of G. pelli. Seed \& Hughes (1995) noted that mechanical features of crab claws reflect their functional efficiency in prey handling, and that crabs specialising on heavily armoured molluscan prey have claws that are slower but more powerful, as in $P$. africanus. More so, given the near permanent residency of $P$. africanus in the mud, the species does arguably have prolonged access and prey time on the lucinid compared to the mobile G. pelli.

The small-sized individuals $(2.5 \mathrm{~mm})$ measured are considered recruits. Presence of these individuals in the population every month suggests that $K$. rhizoecus is multivoltine (Fig. 3). The species' continuous reproductive activity is guaranteed by the stable and numerous numbers of reproductively active individuals; taken presumably to be individuals within 5.5-7.4 class length, which incidentally dominate the population year-round. Differences in monthly recruitment (Fig. 3) observed in the lucinid population may be due to subtle unpredictable changes in environmental conditions that govern reproduction and reproductive success (Cardoso et al., 2007) in such unstable estuarine environment (McLusky, 1989). Recruitment is, however, not directly influenced by reproductive outputs, but by complexes of biological interaction and environmental conditions like temperature (Diederich et al., 2005 cited in Cardoso et al., 2007). Unfortunately, $K$. rhizoecus' continuous recruitment coupled with short longevity and indiscernible shell growth marks (expected in such tropical setting) hinder direct age determination through annuli counts, and makes cohort separation and tracking through modal analysis in the population impossible (see Fig. 2).

The bivalve maintains a moderate growth coefficient $\left(K=2.50\right.$ year $\left.^{-1}\right)$ and a high mortality rate $(Z=7.79)$. Stern-Pirlot \& Wolff (2006) calculated a much lower $K(0.141)$ and $Z(0.36-0.68)$ for Anadara tuberculosa along the Pacific coast of Costa Rica. Since no fishery exists for $K$. rhizoecus at Bodo Creek and it has not been reported elsewhere in the Niger Delta, we surmise that total mortality equals natural mortality for the species. With a high turnover rate in the face of no human predation, and in relatively undisturbed habitat (i.e. in terms of physical disturbance), it appears predation is critical in determining population structure and density of the lucine at the Sivibilagbara swamp.

Many investigations have indicated that animals preserved with formalin loose considerable weights 
over time (Howmiller, 1972), and that the loss in biomass may cease about 4 months post-preservation (Leuven et al., 1985; also see Wolff et al., 1993). In this study, biomass was assessed 1-year post-collection. It is very likely that the $3.915 \mathrm{~g} \mathrm{~m}^{-2}$ calculated (Table 1) is lower than the actual dry tissue weight the lucinid would have yielded if standing crops were measured directly on fresh samples (Wolff et al., 1993); weight loss seems inevitable even though borax was used to counteract the tissue-attack of formalin. The percentage loss in weight due to formalin was not determined, and there are no records for the species either. Thus, we ignore the prompting of possible increment of our biomass value by certain arbitrary percent. The formalin weight-loss notwithstanding, the lucinid biomass calculated compares favourably with biomasses of other bivalves from the neighbouring Andoni tidal flats (Ansa, 2004). She measured mean biomasses of 0.72 and $1.805 \mathrm{~g} \mathrm{~m}^{-2}$ for Tagelus adansonii and Pitaria tumens, respectively.

The rationale behind the calculation of production, biomass ratio $(\mathrm{P} / \mathrm{B})$, is that it allows populations of different biomass to be compared on a common basis (Gray, 1981). No previous data exist on the biomass of $K$. rhizoecus, thus intra-species comparison of $\mathrm{P} / \mathrm{B}$ is impossible in the circumstance. However, our P/B value calculated for the lucinid at Sivibilagbara may be compared with those of some other bivalves species from the Niger Delta (Ansa, 2004) and elsewhere (Gray, 1981). The P/B value for $K$. rhizoecus appears to be on the high side. On the other hand, caution is needed when comparisons are made since our study was made in one locality and lasted only 1 year.

The studied swamp qualifies to be called a refuge, at least, for the lucinid species and for Upogebia fulcata (see discussion below). According to Green \& Craig (1999), a refuge is a protected area that maintains a viable population of organisms, which may contribute recruits to surrounding areas. Sivibilagbara swamp, at least, satisfies the viable population criterion for $K$. rhizoecus because the size distribution had been relatively stable coupled with the super-abundances recorded throughout the study. The refugia argument is further reinforced by the impressive number of Upogebia fulcata recorded at the site. Chindah \& Hart (2000) found that Upogebia spp. are increasingly disappearing from estuarine environments in the Niger Delta where they hitherto occurred at many locations in large numbers and attribute the declining trend to human activities.

More so, oil production - the lead cause of environmental degradation in the Niger Delta-was suspended in Ogoni, where Bodo Creek belongs, since 1993 following organised protest by the locals. The temporary suspension notwithstanding defects on Trans-Niger pipelines traversing Ogoni to Bonny Terminal potentially render the area prone to oil spillages. However, Bodo Creek has not experienced oil spills since the 1986 incident up to the time of our study. Only the neighbouring $K$. Dere spill (CEHRD, 2006) affected part of the Kpador section of Bodo Creek. Thus, our sampled area (Sivibilagbara swamp), located at the Dor Nwezor, had no physical presence of oil and did not show detectable signs of chronic oil contamination.

\section{Conclusion}

Although $K$. rhizoecus does not have any direct economic benefit at Bodo Creek and other parts of the Niger Delta where it is endemic, its huge density and tissue dry weights at Sivibilagbara swamp in Bodo Creek suggest that the species occupies essential links in food webs, upon which humans inalienably depend. The huge densities of the lucine at Sivibilagbara, a site comparable to other mangrove swamps at Bodo Creek and elsewhere in the Niger Delta (Oliver, 1986), reinforce a recent recommendation (Francis \& Zabbey, 2007) for deliberate designation of mangrove protected areas (MPAs) to stem the tide of biodiversity losses in the Niger Delta. The region has been rated critical to the conservation of biodiversity on the west coast of Africa.

Even though several details emerged from the onesite 1-year study, the findings are unlikely a holistic representation of the species at large. However, ultimately, the results compliment the pioneering data base (Oliver, 1986) and offer opportunities for future research on the West African lucinid populations, especially in the areas of reproductive biology, larval ecology, nutrition and inter-species interactions.

Acknowledgments The first author is highly grateful to PADI Foundation, California, USA, for the grant provided in support of his doctoral research, with which this study was made possible. He thanks John Gbei, Baridilo Kemsi, Peter Nwinkiri, Baribefe Bornu and Cletus Sibe for assisting in the 
field data collection. Uyi Hanson assisted in the laboratory analysis. Special thanks are due to Dr. Robert Molenbeek (University of Amsterdam Museum) for confirming the identity of the species. Finally, our appreciation is due to John Taylor, Emily Glover and Rudo von Cosel for generously providing their published articles on the family Lucinidae.

Open Access This article is distributed under the terms of the Creative Commons Attribution Noncommercial License which permits any noncommercial use, distribution, and reproduction in any medium, provided the original author(s) and source are credited.

\section{References}

Amnesty International, 2009. Nigeria: Petroleum, Pollution and Poverty in the Niger Delta. Amnesty International Secretariat, London.

Ansa, E. J., 2004. Studies on the benthic macrofauna of the Andoni flats in the Niger Delta Area of Nigeria. Unpublished Ph.D. Thesis, University of Port Harcourt.

Barnes, P. A. G. \& C. S. Hickman, 1999. Lucinid bivalves and marine angiosperms: a search for causal relationships. In Walker, D. I. \& F. E. Wells (eds), The Seagrass Flora and Fauna of Rottnest Island, Western Australia. Western Australian Museum, Perth: 215-238.

Beukema, J. J., 1993. Successive changes in distribution patterns as an adaptive strategy in the bivalve Macoma balthica (L.) in the Wadden Sea. Helgolander Wissenschaftliche Meeresuntersuchungen 47: 287-304.

Cardoso, J. F. M. F., H. W. van der Veer \& S. A. L. M. Kooijman, 2006. Body-size scaling relationships in bivalve species: a comparison of field data with predictions by dynamic energy budget (DEB) theory. Journal of Sea Research 56: 125-139.

Cardoso, J. F. M. F., R. Dekker, I. J. Witte \& H. W. van der Veer, 2007. Is reproductive failure responsible for reduced recruitment of intertidal Mytilus edulis L. in the western Dutch Wadden Sea? Marine Biodiversity 37: 83-92.

Carney, R. S., 1994. Consideration of the oasis in analogy for chemosynthetic communities at the Gulf of Mexico hydrocarbon vents. Geo-Marine Letters 14: 149-159.

CEHRD, 2006. Training of rural conservationists to carry out re-vegetation of mangrove forest in a crude oil polluted swamp, in Bara-Nwezor village, Bodo-City, Ogoni, Rivers State, Nigeria. A project report of the Centre for Environment, Human Rights and Development (CEHRD). www.cehrd.org.

Chindah, A. C. \& A. I. Hart, 2000. Occurrence and distribution of epifauna and infauna Community in shallow mangrove wetland in the Tropical West African region. African Journal of Environmental Studies 1: 76-83.

Contessa, L. \& F. L. Bird, 2004. The impact of bait-pumping on populations of the ghost shrimp Trypaea australiensis Dana (Decapoda: Callianassidae) and the sediment environment. Journal of Experimental Marine Biology and Ecology 304: 75-97.
Dankers, N. \& D. R. Zuidema, 1995. The role of Mussel (Mytilus edulis) and mussel culture in the Dutch Wadden Sea. Estuaries 18: 71-80.

Dankers, N. M. J. A., M. Herley, P. S. Kristen, H. Michaelis, G. Milht, H. Nehls \& M. Ruth, 1999. Blue mussels and blue mussel beds in the littoral. In de Jong, F., J. F. Bakker, C. J. M. van Berkel, N. M. J. A. Dankers, K. Dahl, C. Gatje, H. Marencic \& P. Potel (eds), Wadden Sea Quality Status Report 1999. Wadden Sea Ecosystem No. 9, Common Wadden Sea Secretariat, Trilateral Monitoring and Assessment Group, Quality Status Report Group, Wilhelmshaven, Germany: 141-145.

Diederich, S., G. Nehls, J. E. E. van Beusekom \& K. Reise, 2005. Introduced Pacific oysters may cause restrictions on habitat use by native mussels in Wadden Sea: invasion accelerated by warm summers? Helgoland Marine Research 59: 97-106.

Francis, A. \& N. Zabbey, 2007. Marine protected areas and the benefits of their establishment. In Araoye, P. A., I. A. Adikwu \& R. O. Banke (eds), Proceedings of the 22nd Annual Conference of the Fisheries Society of Nigeria (FISON), Kebbi State, Nigeria, 12-16 November 2007.

Gayanilo, F. C. Jr., M. Soriano \& D. Pauly, 1989. A Draft Guide to the Compleat ELEFAN. ICLAM Software 2: $70 \mathrm{pp}$.

Gayanilo, F. C. Jr., P. Sparre \& D. Pauly, 2005. FAO-ICLARM Stock Assessment Tools II. Revised version. Worldfish Center, Food and Agriculture Organization of the United Nations, Rome.

Glover, E. A. \& J. D. Taylor, 2001. Systematic revision of Australian and Indo-Pacific Lucinidae (Mollusca: Bivalvia): Pillucina, Wallucina and descriptions of two new genera and four new species. Records of the Australian Museum 53: 263-292.

Glover, E. A., J. D. Taylor \& A. A. Rowden, 2004. Bathyaustriella thionipta, a new lucinid bivalve from a hydrothermal vent on the Kermadec Ridge, New Zealand and its relationship to shallow-water taxa (Bivalvia: Lucinidae). Journal of Molluscan Studies 70: 283-295.

Gray, J. S., 1981. The Ecology of Marine Sediments. Cambridge University Press, Cambridge.

Green, A. \& P. Craig, 1999. Population size and structure of giant clams at Rose Atoll, an important refuge in the Samoan Archipelago. Coral Reefs 18: 205-211.

Howmiller, R. P., 1972. Effects of preservation on weights of some common macrobenthic invertebrates. Transactions on American Fisheries Society 101: 743-746.

Hynes, H. B. N., 1961. The invertebrate fauna of the Welsh mountain stream. Archiv fur Hydrobiologie 57: 344-388.

Hynes, H. B. N. \& M. H. Coleman, 1968. A simple method of assessing the annual production of stream benthos. Limnology and Oceanography 13: 569-573.

Lebata, J. H. L., 2001. Oxygen, sulphide and nutrient uptake of the mangrove mud clam Anodontia edentula (Family: Lucinidae). Marine Pollution Bulletin 42: 1133-1138.

Leuven, R. S. E. W., T. C. M. Brock \& H. A. M. van Druten, 1985. Effects of preservation on dry- and ash-free dry weight biomass of some common aquatic macro-invertebrates. Hydrobiology 127: 151-159.

Malaquias, M. A. E. \& M. J. Sprung, 2005. Population biology of the cephalaspidean mollusc Haminoea orbignyana in a 
temperate coastal lagoon (Ria Formosa, Portugal). Estuarine, Coastal, and Shelf Science 63: 177-185.

McLusky, D. S., 1989. The Estuarine Ecosystem. Chapman and Hall, New York.

O'Hanlon, R. P. \& T. Bolger, 1997. Biomass, growth and secondary production of Arcitalitrus dorrieni (Crustacea: Amphipoda: Talitridae) at two sites in Co. Galway, Ireland. Journal of Zoology 241: 409-428.

Oliver, G. P., 1986. A new lucinid bivalve from the Niger Delta and an appraisal of the Loripes group (Bivalvia, Lucinacea). Basteria 50: 47-64.

Oliver, G. P. \& A. M. Holmes, 2006. A new species of Lucinoma (Bivalvia: Lucinoidea) from the oxygen minimum zone of the Oman Margin, Arabian Sea. Journal of Conchology 39: 63-77.

Onwugbuta-Enyi, J., N. Zabbey \& E. S. Erondu, 2008. Water quality of Bodo Creek in the lower Niger Delta basin. Advances in Environmental Biology 2(3): 132-136.

Pauly, D., 1986. On improving operation and use of the ELEFAN programs. Part II. Improving the estimation of $L_{\infty}$. ICLAM Fishbyte 4(1): 18-20.

Pauly, D., 1987. A review of the ELEFAN system for analysis of length-frequency data and aquatic invertebrates. In Pauly, D. \& G. R. Morgans (eds), Length-Based Methods in Fisheries Research. ICLAM Conference Proceedings 13: 7-34.

Powell, C. B., A. I. Hart \& S. Deekae, 1985. Market survey of the periwinkle Tympanotonus fuscatus in Rivers State: sizes, prices and exploitation levels. In Ha, E. A., T. O. Ajayi, B. Ezenna, A. A. Olaniawo, R. E. K. Udolisa, P. A. Taggert (eds), Proceedings of the 4th Annual Conference of the Fisheries Society of Nigeria (FISON): 55-61.

Rees, H. L., 1984. A note on mesh selection and sampling efficiency in benthic studies. Marine Pollution Bulletin 15: 225-229.

Reid, R. G. B. \& D. G. Brand, 1986. Sulphide-oxidizing symbiosis in Lucinaceans: implications for bivalve evolution. Veliger 29: 3-24.

Reid, R. G. B. \& S. Slack-Smith, 1998. Superfamily Lucinoidea. In Beesley, P. L., G. J. B. Ross \& A. Wells (eds), Mollusca: The Southern Synthesis. Fauna Australia. Part A, Vol. 5. SIRO Publishing, Melbourne: 309-315.

Rossi, F. \& M. G. Chapman, 2003. Influence of sediment on burrowing by the soldier crab Mictyris longicarpus Labeille. Journal of Experimental Marine Biology and Ecology 289: 181-195.

Rossi, R. M., F. Forster, F. M. Monserrat, A. Ponti, T. Terlizzi, J. Ysebaert \& J. Middelburg, 2007. Human trampling as short-term disturbance on intertidal mudflats: effects on macrofaunal biodiversity and population dynamics of bivalves. Marine Biology 151: 2077-2090.
Salas, C. \& J. Woodside, 2002. Lucinoma kazani n.sp. (Mollusca: Bivalvia): evidence of a living benthic community associated with a cold seep in the eastern Mediterranean. Deep-Sea Research 149: 991-1005.

Sasekumar, A., 1974. Distribution of macrofauna on a Malayan mangrove shore. Journal of Animal Ecology 43: 51-69.

Sasekumar, A., 1984. Methods for the study of mangrove fauna. In Snedaker, S. C. \& J. G. Snedaker (eds), The Mangrove Ecosystem: Research Methods. UNESCO, UK.

Sasekumar, A., T. L. Ong \& K. I. Thong, 1984. Predation of mangrove fauna by marine fishes. In E. Soepadmo et al. (eds), Proceedings of Asian Symposium Mangrove Environment - Research and Management: 378-384.

Schweimanns, M. \& H. Felback, 1985. Significance of the occurrence of chemoautotrohic bacterial endosymbionts in lucinid clams from Bermuda. Marine Ecology Progress Series 24: 113-120.

Seed, R. \& R. N. Hughes, 1995. Criteria for prey size-selection in molluscivorous crabs with contrasting claw morphologies. Journal of Experimental Marine Biology and Ecology 193: 177-195.

Steiner, R., 2008. Double standards? International standards to prevent and control pipeline oil spills compared with Shell practices in Nigeria. A report submitted to Friends of the Earth, Netherlands.

Stern-Pirlot, A. \& M. Wolff, 2006. Population dynamics and fisheries of Anadara tuberculosa (Bivalvia: Arcidae) along the Pacific coast of Costa Rica. Revista de Biologia Tropical 54(Suppl 1): 87-99.

Taylor, J. D. \& E. A. Glover, 2000. Functional anatomy, chemosymbiosis and evolution of the Lucinidae. In Harper, E. M., J. D. Taylor \& J. A. Crame (eds), The Evolutionary Biology of the Bivalvia. Geological Society, London, Special Publication, vol. 177: 207-225.

Taylor, J. D. \& E. A. Glover, 2006. Lucinidae (Bivalvia) - the most diverse group of chemosymbiotic molluscs. Zoological Journal of Linnean Society 148: 421-438.

UNDP, 2006. Niger Delta Development Report. Perfect Printers Limited, Abuja.

von Cosel, R., 2006. Taxonomy of tropical West African bivalves. V1. Remarks on Lucinidae (Mollusca, Bivalvia), with description of six new genera and eight new species. Zoosystema 28: 805-851.

Wolff, W. J., A. G. Duiven, P. Esselink, A. Gueye, A. Meijboom, G. Moerland \& J. Zegers, 1993. Biomass of macrobenthic tidal flat fauna of the Banc d'Arguin, Mauritania. Hydrobiology 258: 151-163.

Zwarts, L. \& P. Esselink, 1989. Versatility of male curlews Numenius arquata preying upon Nereis diversicolor: deploying contrasting capture modes dependent on prey availability. Marine Ecology Progress Series 56: 255-269. 